\title{
Investigation of Citric Acid By-Products from Rice Produced by Microbial Fermentation on Growth Performance and Villi Histology of Thai Broiler Chicken (KKU 1)
}

\author{
Mutyarsih Oryza.S ${ }^{1}$, Sawitree Wongtangtintharn ${ }^{1, *}$, Bundit Tengjaroenkul ${ }^{2}$, Anusorn Cherdthong ${ }^{1}$, \\ Sirisak Tanpong ${ }^{1}$, Padsakorn Pootthachaya ${ }^{1}{ }^{1}$, Wuttigrai Boonkum ${ }^{1}$ and Nisakon Pintaphrom ${ }^{1}$ \\ 1 Department of Animal Science, Faculty of Agriculture, Khon Kaen University, Khon Kaen 40002, Thailand; \\ mutyarsih.or@kkumail.com (M.O.); anusornc@kku.ac.th (A.C.); sirisakt@kkumail.com (S.T.); \\ padsakornp@kkumail.com (P.P.); wuttbo@kku.ac.th (W.B.); nisakon_m@kkumail.com (N.P.) \\ 2 Department of Veterinary Public Health, Faculty of Veterinary Medicine, Khon Kaen University, \\ Khon Kaen 40002, Thailand; btengjar@kku.ac.th \\ * Correspondence: sawiwo@kku.ac.th
}

check for updates

Citation: Oryza.S, M.;

Wongtangtintharn, S.; Tengjaroenkul, B.; Cherdthong, A.; Tanpong, S.; Pootthachaya, P.; Boonkum, W.; Pintaphrom, N. Investigation of Citric Acid By-Products from Rice Produced by Microbial Fermentation on Growth Performance and Villi Histology of Thai Broiler Chicken (KKU 1). Vet. Sci. 2021, 8, 284. https://doi.org/10.3390/ vetsci8110284

Academic Editor: Fulvia Bovera

Received: 8 October 2021

Accepted: 18 November 2021

Published: 20 November 2021

Publisher's Note: MDPI stays neutral with regard to jurisdictional claims in published maps and institutional affiliations.

\begin{abstract}
This study was conducted with Thai broiler chicken (KKU 1) to investigate the effect of citric acid by-products from rice (CABR) on growth performance and villi histology. A total of 192 broiler chicks were subject to three dietary treatments, including $0 \%$ CABR, 3\% and 6\% of dry matter. Body weight gains, feed intake, feed conversion ratio, survival rate, and production index (body weight gain, feed intake, feed conversion ratio, survival rates, and productive index, respectively) were considered for growth performance evaluation. Villi height $(\mu \mathrm{m})$, crypt depth $(\mu \mathrm{m})$, and villi: crypt ratio were recorded for the villi histological measurement. The performance did not show a significant effect when compared with the control group during at ages ranging from 1 to 56 days. Villi histology indicate a significant effect on villi height $(\mu \mathrm{m})$, crypt depth $(\mu \mathrm{m})$, and villi: crypt of broiler chicks compared with the control group. Also, the use of $3 \%$ CABR caused a reduction microbial contamination in chicken fecal matter. In conclusion, supplementation of CABR had no negative effects on growth performance of Thai broiler chicken (KKU 1). Also, the addition of $3 \% \mathrm{CABR}$ to the feed might help reduce fecal microbial contamination and affect the villi histology of Thai broiler chickens (KKU 1).
\end{abstract}

Keywords: citric acid rice; Thai broiler chicken; villi histology; microbial contamination

\section{Introduction}

Citric acid is the world's second-largest fermentation product and is both a weak and an essential organic acid. Commonly used as a feed additive, citric acid produces more than 1.7 million tons per year and is expected to increase every year [1]. Also, the demand for citric acid production has rapidly increased. Thus, the researcher and industries look for the raw materials that could reduce citric acid productions cost. Some study conducted for use some agriculture production to become citric acid as a raw material [2]. Nowadays in Thailand, rice is the major locally produced crop, which amounted to 20.7 million metric tons in 2019 [3]. Thus, rice certainly has the opportunity to be an ingredient to produce citric acid. The ability of rice and potato as an extract to produce citric acid was analyzed by Kudzai et al. [2] in order to meet the high demand for citric acid. The result was shown that rice could provide the highest production of citric acid, and rice extract media proved to be more useful than potato extract media. In China, rice has also become a popular raw material for citric acid production, and the obtained method was to use fermentation process on rice to produce citric acid [4]. Submerged fermentation with Aspergillus niger is commonly used to produce citric acid in the commercial sector [5]. The advantages of using Aspergillus niger over other potential citric acid producing microorganisms include its high 
citric acid productivity at low $\mathrm{pH}$ without toxic metabolite secretion, ease of handling, and ability to ferment a wide range of inexpensive raw materials. The ability of this fungus to convert existing sugars in the fermentation media to the citric acid is of very high efficiency, ranging from 70-90\%. [6]. Obtaining citric acid production by the fermentation of rice using Aspergillus niger was studied by Kudzai et al. [2]. The result showed that rice extract media contains, and readily makes, more sugars available, resulting in higher citric acid production levels.

Besides, global citric acid production generates waste residue of the amount of $50-60 \%$ [7]. The waste from citric acid by-products (CABR) can cause pollution and environmental problems when not managed properly. The waste from citric acid by-products contains sugars, cellulose, hemicellulose, starch, and also protein, which can be utilized for animal feed. By-products from the citrus industry can make an important addition to the amount of locally produced feed for animals. The benefits of the by-product are directly related to its low-cost feed additive, which can lower the cost of animal feed when used as a feed substitute [8]. Citric acid by-products retain organic acids, which could be good for gut health and stimulate poultry immune responses [9]. Tanpong et al. [10] reported citric acid by-product from cassava could be an alternative energy source for animal feed, due to its containing $3.59 \mathrm{Mcal} / \mathrm{kg}$ and $6.11 \%$ of crude protein, which makes this by-product a possible alternative feed ingredient for animals and the advantage of this by-product is related to reduced feed cost, ecofeed, and reduction in waste from various industries. Mehdikhany et al. [11] reported that citric acid by-product contains $14.4 \%$ of crude protein and $4499.7 \mathrm{Kcal} / \mathrm{kg}$ of gross energy. This implies that the level of $5 \%$ citric acid by-product is suitable for broiler diets. S. Oryza et al. [12] reported that citric acid by-product from rice (CABR) contains $19.80 \%$ of crude protein, $11.97 \%$ of crude fiber, and $4005.72 \mathrm{Kcal} / \mathrm{kg}$ of energy, which implies that CABR could be utilized as an energy source for animal feed. Also, the result showed that CABR is not contaminated with aflatoxin or fumonisin, which makes this by-product possibly safe for animal feed. The objective of the present study was to utilize the CABR as a feed ingredient in Thai broiler chicken (KKU 1) in terms of growth performance and digestive performance, such as villi histology and microbial contamination on fecal matter.

\section{Materials and Methods}

\subsection{Production Techniques of Citric Acid}

CABR was obtained from the factory in the eastern part of Thailand and provided by the PS Nutrition Company Limited, Bangkok, Thailand. In the production, rice was used as a raw material substrate to produce citric acid by fermentation with A.nigger [13]. The fermentation process was of $144 \mathrm{~h}$ duration, under optimized temperature and moisture. First, rice as a substrate was milled and boiled before the fermentation process. The second step was adding the microbial (A.nigger) in the fermentation tank. After that, filtration process was used to separate the liquid and the waste product. The liquid was used to produce citric acid, and the waste product was dried in the sun or in an oven at the temperature of $95^{\circ} \mathrm{C}$. After the drying process, the CABR sample was used in this study.

\subsection{Animals and Experimental Design}

CABR was provided by the PS Nutrition Company Limited, Bangkok, Thailand. The chemical composition was here investigated in this study based on results from preliminary experiments, and then calculated for animal experiments [12]. The crude protein (CP) was $19.80 \%$ and gross energy (GE) was $4005.72 \mathrm{Kcal} / \mathrm{kg}$.

This research used Thai broiler chicken (KKU 1) as an animal trial. A KKU 1 chicken is an indigenous hybrid chicken breed, developed by the Network Center for Animal Breeding and Omics Research. Thai broiler chickens have a terminal hybrid of $75 \%$ commercial broiler breed and $25 \%$ of Thai native chicken breed [14].

A total of 192 Thai broiler chicken (KKU 1) birds (one day old) and of mixed sex (male to female 1:1) were used. All animals used were consistent, and there were no differences in 
body weight throughout this study. The chickens were obtained from the Network Center for Animal Breeding and Omics Research, Faculty of Agriculture, Khon Kaen University, Thailand. The birds were randomly distributed into one of the three dietary treatments: (1) control group $0 \%$ of CABR, (2) $3 \%$ of CABR, and (3) $6 \%$ of CABR as corn replacement (Table 1) in a completely randomized design with four replications and 16 birds per pen or replication. This experiment was conducted on the Poultry Farm of the Faculty of Agriculture, Khon Kaen University, Thailand. This experiment provided water and feed ad libitum to birds for 56 days, divided into three of feeding periods, period: (1) period 1 (1-21 days), (2) period 2 (22-49 days), and period 3 (50-56 days).

Table 1. Feed ingredient of experimental diet period 1-3.

\begin{tabular}{|c|c|c|c|c|c|c|c|c|c|}
\hline \multirow{4}{*}{ Ingredient $(\%)$} & \multicolumn{9}{|c|}{ Citric Acid By-Product, \% Dry Matter } \\
\hline & \multicolumn{3}{|c|}{0} & \multicolumn{3}{|c|}{3} & \multicolumn{3}{|c|}{6} \\
\hline & \multicolumn{3}{|c|}{ Period } & \multicolumn{3}{|c|}{ Period } & \multicolumn{3}{|c|}{ Period } \\
\hline & 1 & 2 & 3 & 1 & 2 & 3 & 1 & 2 & 3 \\
\hline Corn meal & 50.00 & 55.57 & 59.47 & 48.00 & 53.47 & 57.37 & 46.00 & 51.37 & 55.27 \\
\hline Soybean meal & 26.90 & 19.30 & 12.46 & 25.80 & 18.30 & 11.46 & 24.70 & 17.30 & 10.46 \\
\hline Full fat soybean & 17.00 & 19.00 & 22.00 & 17.00 & 19.00 & 22.00 & 17.00 & 19.00 & 22.00 \\
\hline Dicalcium phosphate \% P21 & 1.80 & 1.60 & 1.50 & 1.80 & 1.60 & 1.50 & 1.80 & 1.60 & 1.50 \\
\hline Limestone & 1.60 & 1.40 & 1.30 & 1.60 & 1.40 & 1.30 & 1.60 & 1.40 & 1.30 \\
\hline DL-Met & 0.25 & 0.20 & 0.17 & 0.25 & 0.20 & 0.17 & 0.25 & 0.20 & 0.17 \\
\hline Lysine & 0.20 & 0.18 & 0.15 & 0.20 & 0.18 & 0.15 & 0.20 & 0.18 & 0.15 \\
\hline Rice crude bran oil & 1.50 & 2.00 & 2.20 & 1.60 & 2.10 & 2.30 & 1.70 & 2.20 & 2.40 \\
\hline Salt & 0.30 & 0.30 & 0.30 & 0.30 & 0.30 & 0.30 & 0.30 & 0.30 & 0.30 \\
\hline Choline chloride $60 \%$ & 0.10 & 0.10 & 0.10 & 0.10 & 0.10 & 0.1 & 0.10 & 0.10 & 0.10 \\
\hline Premix & 0.35 & 0.35 & 0.35 & 0.35 & 0.35 & 0.35 & 0.35 & 0.35 & 0.35 \\
\hline Citric acid by-product rice & 0.00 & 0.00 & 0.00 & 3.00 & 3.00 & 3.00 & 6.00 & 6.00 & 6.00 \\
\hline Total & 100.00 & 100.00 & 100.00 & 100.00 & 100.00 & 100.00 & 100.00 & 100.00 & 100.00 \\
\hline \multicolumn{10}{|l|}{ Calculated } \\
\hline $\mathrm{CP}, \%$ & 22.39 & 20.05 & 18.29 & 22.33 & 20.02 & 18.26 & 22.26 & 19.99 & 18.23 \\
\hline $\mathrm{ME}, \mathrm{Kcal} / \mathrm{kg}$ & 3013 & 3129 & 3209 & 3004 & 3118 & 3198 & 2994 & 3108 & 3188 \\
\hline
\end{tabular}

\subsection{Data Collection}

\subsubsection{Growth Performance}

During the study, the data such as body weight, body weight gain, feed intake, feed conversion ratio, and productive index (BW, BWG, FI, FCR, and PI, respectively) were recorded for each period and calculated for growth performance following the method of Singh [15]. All birds from each treatment were weighed weekly using electronic digital weighing machine to obtain the body weight. The amount of added feed to each pen and feed residue was recorded daily using electronic digital weighing machine. Feed consumption was calculated on a per period basis: (1) starter period (1-21 days), (2) growth period (22-49 days), (3) finishing period (50-56 days), and (4) overall period (1-56 days). BWG, FI, and FCR each period were calculated. In all trials, mortality was recorded and reported as a cumulative percentage and for PI, it was calculated following this formulation:

$$
\mathrm{PI}=\frac{\text { body weight } \times \text { survival rate }(\%) \times 100}{\text { age }(\text { days }) \times \text { FCR }}
$$


Productive growth performance:

$$
\begin{gathered}
\text { BWG }=\frac{\text { final weigh } \times \text { initial weight }}{\text { number of birds }} \\
\text { FI }=\frac{\text { Total feed consumption }}{\text { number of birds }} \\
\text { FCR }=\frac{\text { feed intake }}{\text { body weight gain }} \\
\text { Survival rates }(\%)=\frac{\text { Number of initial birds }- \text { Number of dead birds }}{\text { body number of initial birds }}
\end{gathered}
$$

\subsubsection{Villi Histology}

Following the method of De Verdal et al. [16], two birds of each treatment and each replication were sacrificed by cervical dislocation at the end of the experiment; sections from the middle of the duodenum, jejunum, and ileum were excised. The samples were fixed in $4 \%$ buffered formalin. The tissue processing consisted of dehydration, and clearing, with paraffin wax. Tissue sections, $5 \mu \mathrm{m}$ thick (three cross-sections from each sample), were cut by a microtome and were fixed on slides. The sample was measured with an optical microscope (Eclipse E600, Nikon Corp., Tokyo, Japan) at $4 \times$ magnification. The microscope was fitted with a video camera (XC77E, Sony Corp., Tokyo, Japan) and the images were analyzed using image-analysis software Axio vision imaging system, 2018 version (Carl Zeiss, Co., Ltd., Seoul, Korea). The height of each villus was measured from the top of the villus to the crypt transition, and the crypt depth was defined as the invagination between two villi. The heights of 6 villi and the depths of 6 crypts were measured per animal (12 position of villus height and crypt depth per treatment).

\subsubsection{Microbial Contamination on Fecal Matter}

In each of three replication trails, excrement samples were taken from the chicken cages at the end of the current experiment (56-day). The fecal content was pooled then examined at the Veterinary Diagnostic Laboratory Faculty of Veterinary Medicine Khon Kaen University, Thailand. A coliform/escherichia coli test was performed using the 3M Petrifilm Rapid E.coli/coliform counting plate, which was validated according to the AOAC Validation Guidelines following the AOAC Official Method of Analysis SM process [17]. A fecal sample was diluted with sterile saline peptone water in ratios ranging from 10:1 to 10:10, and the solutions were mixed thoroughly with a vortex mixer. One milliliter from each sample dilution was plated onto a single 3M Petrifilm Rapid E. coli/Coliform Count Plate. The plates were incubated at $37^{\circ} \mathrm{C}$ for 18 to $24 \mathrm{~h}$. After incubation, colony-forming units (CFU) were counted and recorded. The total coliform was count was indicated by red colonies as a result of gas production, while E. coli presented in blue color colonies both with and without gas production.

\subsection{Statistical Analysis}

The data were analyzed with a one-way analysis of variance (ANOVA) using the general linear model (GLM) based on SAS (SAS, Institute Inc., Cary, NC, USA, 2015) [18]. A completely randomized design was used for all parameters. Differences among means by Duncan's new multiple range tests, with $p<0.05$ were accepted as statistically significant differences.

\section{Results}

\subsection{Growth Performance}

The growth performance, initial weight, BWG, FI, FCR, SR, and production index (PI) of Thai native chicken fed with CABR was performed in Table 2. The results reveal that supplementation with $\mathrm{CABR}$ at 3 to $6 \%$ in the diet had no effect on growth performance $(p<0.05)$. 


\subsection{Villi Histology}

Villi histological examinations of the Thai native chicken (KKU 1) are shown in Figure 1 and Table 3. The results showed that the addition of CABR to the diet of Thai broiler chickens (KKU 1) did affect villi histological parameters, including villi height, crypt depth, and villi:crypt ratio ( $\mathrm{VH}, \mathrm{CD}$, and $\mathrm{V}: \mathrm{C}$, respectively). It could be observed that the addition of citric acid by-product (CABR) showed no significant effect in villi height section (duodenum and ileum), but had a significant effect on the jejunum. The addition of $3 \%$ and $6 \%$ CABR caused a significant decrease effect in CD when compared with the control group $(p<0.05)$, and the addition of CABR has a significant effect on V:C ratio in the duodenum, jejunum, and ileum when compared with the control group $(p<0.05)$.

Table 2. Citric acid by-product from rice (CABR) utilization on growth performance of Thai native chicken (KKU 1) throughout $1-56$ days.

\begin{tabular}{|c|c|c|c|c|}
\hline \multirow[t]{2}{*}{ Parameter } & \multicolumn{3}{|c|}{$\begin{array}{c}\text { Citric Acid By-Product Rice, } \\
\text { \% Dry Matter }\end{array}$} & \multirow{2}{*}{$p$-Value } \\
\hline & 0 & 3 & 6 & \\
\hline \multicolumn{5}{|l|}{ Days 1-21 } \\
\hline Initial weight $(\mathrm{g} / \mathrm{b})$ & $32.77 \pm 0.13$ & $32.73 \pm 0.22$ & $32.80 \pm 0.42$ & 0.9496 \\
\hline Body weight (g/b) & $384.16 \pm 30.49$ & $392.22 \pm 11.60$ & $371.96 \pm 26.91$ & 0.5225 \\
\hline BWG $(\mathrm{g} / \mathrm{b})$ & $351.39 \pm 30.59$ & $359.49 \pm 11.71$ & $339.16 \pm 22.21$ & 0.5249 \\
\hline FI $(\mathrm{g} / \mathrm{b})$ & $526.36 \pm 12.39$ & $514.52 \pm 27.59$ & $541.26 \pm 30.79$ & 0.3572 \\
\hline FCR & $1.51 \pm 0.13$ & $1.43 \pm 0.07$ & $1.60 \pm 0.12$ & 0.1305 \\
\hline SR (\%) & $100.00 \pm 0.00$ & $100.00 \pm 0.00$ & $96.88 \pm 3.61$ & 0.1004 \\
\hline PI & $122.65 \pm 18.77$ & $130.72 \pm 7.79$ & $107.89 \pm 14.82$ & 0.1540 \\
\hline \multicolumn{5}{|l|}{ Days 22-49 } \\
\hline Initial weight $(\mathrm{g} / \mathrm{b})$ & $384.16 \pm 30.49$ & $392.22 \pm 11.60$ & $371.96 \pm 26.91$ & 0.5225 \\
\hline Body weight (g/b) & $1461.67 \pm 119.71$ & $1475.26 \pm 23.39$ & $1423.53 \pm 74.98$ & 0.6687 \\
\hline BWG $(\mathrm{g} / \mathrm{b})$ & $1077.51 \pm 100.86$ & $1083.04 \pm 20.84$ & $1051.58 \pm 52.33$ & 0.7813 \\
\hline $\mathrm{FI}(\mathrm{g} / \mathrm{b})$ & $2171.01 \pm 154.87$ & $2158.61 \pm 120.24$ & $2091.71 \pm 46.42$ & 0.6017 \\
\hline FCR & $2.02 \pm 0.17$ & $1.99 \pm 0.08$ & $1.99 \pm 0.13$ & 0.9291 \\
\hline SR (\%) & $93.75 \pm 12.50$ & $95.31 \pm 5.98$ & $96.88 \pm 6.25$ & 0.8825 \\
\hline PI & $140.48 \pm 34.44$ & $144.27 \pm 11.76$ & $142.14 \pm 21.02$ & 0.9759 \\
\hline \multicolumn{5}{|l|}{ Days $50-56$} \\
\hline Initial weight $(\mathrm{g} / \mathrm{b})$ & $1461.67 \pm 119.71$ & $1475.26 \pm 23.39$ & $1423.53 \pm 74.98$ & 0.6687 \\
\hline Body weight (g/b) & $1774.09 \pm 84.51$ & $1770.13 \pm 41.44$ & $1713.49 \pm 116.86$ & 0.5631 \\
\hline BWG $(\mathrm{g} / \mathrm{b})$ & $312.42 \pm 46.64$ & $294.88 \pm 36.02$ & $289.96 \pm 44.29$ & 0.2137 \\
\hline $\mathrm{FI}(\mathrm{g} / \mathrm{b})$ & $875.72 \pm 35.63$ & $866.17 \pm 57.67$ & $946.18 \pm 88.63$ & 0.7649 \\
\hline FCR & $2.87 \pm 0.53$ & $2.97 \pm 0.38$ & $3.30 \pm 0.42$ & 0.3240 \\
\hline SR (\%) & $100.00 \pm 0.00$ & $100.00 \pm 0.00$ & $100.00 \pm 0.00$ & NA \\
\hline PI & $112.97 \pm 19.00$ & $107.92 \pm 14.42$ & $94.54 \pm 20.16$ & 0.3692 \\
\hline \multicolumn{5}{|l|}{ Overall (days 1-56) } \\
\hline Initial weight $(\mathrm{g} / \mathrm{b})$ & $32.77 \pm 0.13$ & $32.73 \pm 0.22$ & $32.80 \pm 0.42$ & 0.9496 \\
\hline Body weight (g/b) & $1774.09 \pm 84.51$ & $1770.13 \pm 41.44$ & $1713.49 \pm 116.86$ & 0.5631 \\
\hline BWG (g/b) & $1741.32 \pm 84.64$ & $1737.40 \pm 41.58$ & $1680.69 \pm 117.07$ & 0.5637 \\
\hline $\mathrm{FI}(\mathrm{g} / \mathrm{b})$ & $3616.28 \pm 255.13$ & $3566.13 \pm 210.28$ & $3597.24 \pm 83.50$ & 0.9364 \\
\hline FCR & $2.08 \pm 0.18$ & $2.05 \pm 0.09$ & $2.15 \pm 0.15$ & 0.6254 \\
\hline SR $(\%)$ & $93.75 \pm 12.50$ & $95.31 \pm 5.98$ & $93.75 \pm 5.10$ & 0.9564 \\
\hline PI & $145.08 \pm 32.35$ & $147.19 \pm 13.96$ & $134.72 \pm 21.75$ & 0.7397 \\
\hline
\end{tabular}

$\overline{\mathrm{BWG}}=$ body weight gain; FI = feed intake; FCR $=$ feed conversion ratio; SR = survival rate; PI = production index and NA = not applicable. 
Table 3. Morphological measurement of villi in Thai native chicken (KKU 1) on duodenum, jejunum, and ileum, fed with citric acid by-product from rice (CABR).

\begin{tabular}{|c|c|c|c|c|}
\hline \multirow{2}{*}{ Parameter } & \multicolumn{3}{|c|}{$\begin{array}{c}\text { Citric Acid By-Product Rice } \\
\% \text { Dry Matter }\end{array}$} & \multirow{2}{*}{$p$-Value } \\
\hline & 0 & 3 & 6 & \\
\hline \multicolumn{5}{|c|}{ Villi height $(\mu \mathrm{m})$} \\
\hline Duodenum & $870.47 \pm 81.71$ & $906.87 \pm 66.01$ & $913.21 \pm 211.12$ & 0.7111 \\
\hline Jejunum & $768.45 \pm 72.05^{\mathrm{a}}$ & $769.87 \pm 70.65^{a}$ & $659.87 \pm 111.45^{b}$ & 0.0047 \\
\hline Ileum & $508.45 \pm 60.63$ & $502.48 \pm 73.23$ & $482.84 \pm 22.94$ & 0.5155 \\
\hline \multicolumn{5}{|c|}{ Crypt depth ( $\mu \mathrm{m})$} \\
\hline Duodenum & $185.59 \pm 9.06^{\mathrm{a}}$ & $173.95 \pm 18.82^{\mathrm{a}}$ & $158.04 \pm 23.91^{\mathrm{b}}$ & 0.0033 \\
\hline Jejunum & $257.66 \pm 24.73^{a}$ & $175.70 \pm 14.49^{b}$ & $156.11 \pm 28.56^{c}$ & 0.0001 \\
\hline Ileum & $172.00 \pm 39.09^{a}$ & $108.98 \pm 20.24^{c}$ & $142.99 \pm 18.02^{b}$ & 0.0001 \\
\hline \multicolumn{5}{|c|}{ Villi: Crypt } \\
\hline Duodenum & $4.68 \pm 0.29^{b}$ & $5.28 \pm 0.78^{a b}$ & $5.81 \pm 1.12^{\mathrm{a}}$ & 0.0067 \\
\hline Jejunum & $2.99 \pm 0.23^{b}$ & $4.42 \pm 0.63^{\mathrm{a}}$ & $4.38 \pm 1.26^{\mathrm{a}}$ & 0.0001 \\
\hline Ileum & $3.23 \pm 1.32^{b}$ & $4.81 \pm 1.30^{\mathrm{a}}$ & $3.41 \pm 0.34^{\mathrm{b}}$ & 0.0020 \\
\hline
\end{tabular}

\pm standard deviation, Figure having different superscripts in the same row differ significantly $(p<0.05)$.

(A)

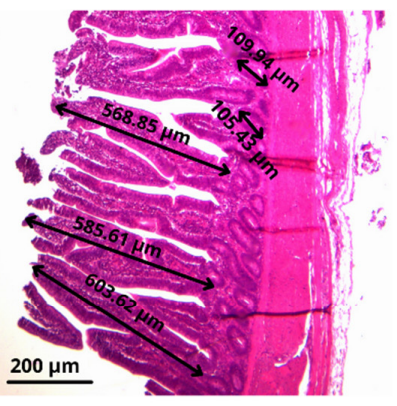

Duodenum

(B)

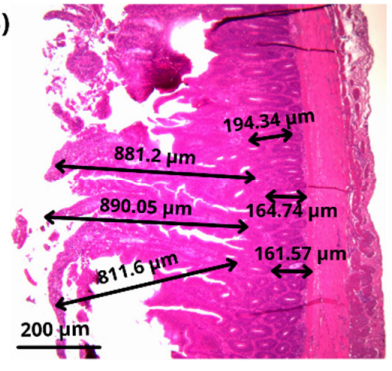

Duodenum

(C)

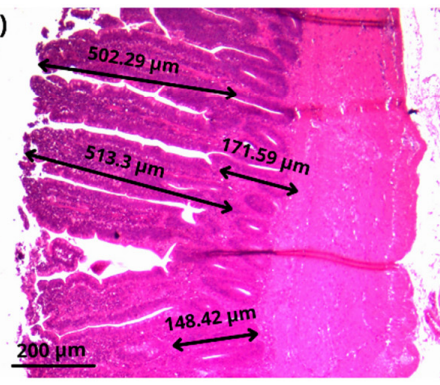

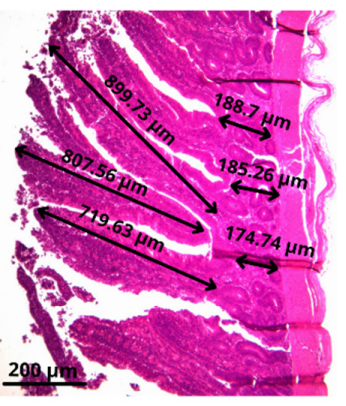

Jejunum

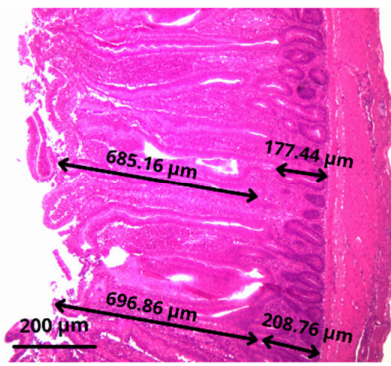

Jejunum

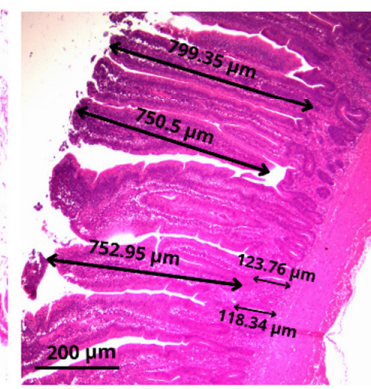

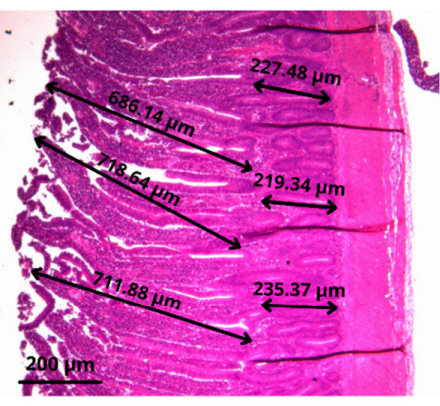

Ileum

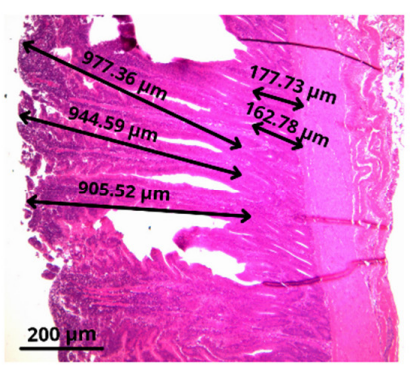

Ileum

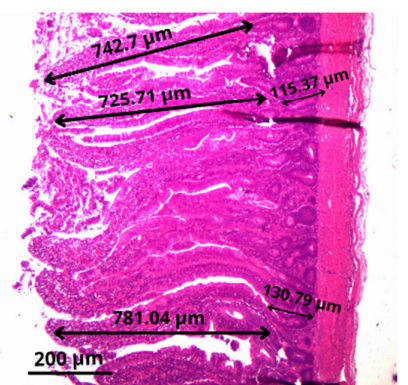

Figure 1. Morphological measurement of villi in Thai native chicken (KKU 1) on duodenum, jejunum, and ileum, fed with citric acid by-product from rice (CABR), (A) control, (B) CABR 3\%, and (C) CABR $6 \%$. 


\subsection{Microbial Contamination on Fecal Matter}

To check for statistical difference of microbial contamination between the treatment, we performed it in the graph (Figure 2). We found that no significant difference between treatment $3 \%$ and $6 \%$ compared with the control $(0 \%)$.

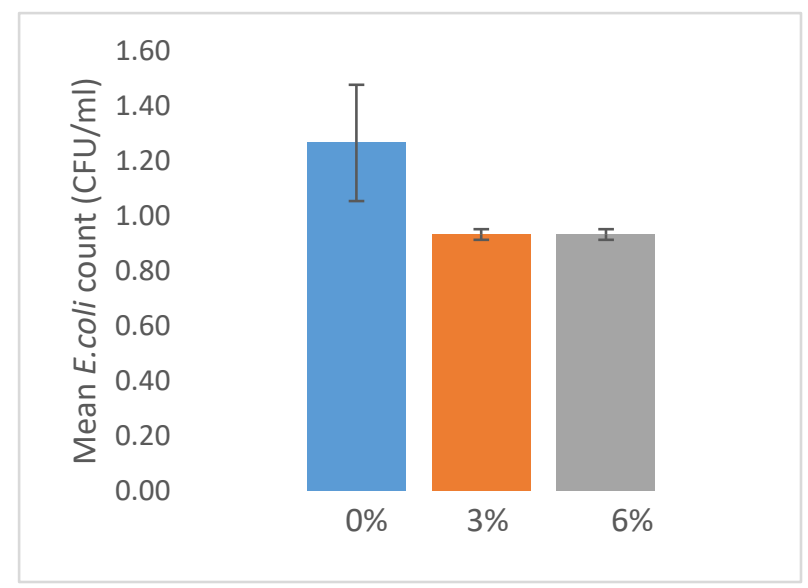

Figure 2. Microbial contamination on fecal matter. Error bars represent \pm standard error.

\section{Discussion}

The effect of CABR inclusion in Thai native chicken (KKU 1) ration during the starter period (day 1-21 days), grower period (22-49 days), finisher period (50-56 days, and overall period (1-56) days) showed that it did not negatively affect the chicken growth performance, compared with the control group $(p<0.05)$. The result disagreed with the previous research of Tanpong [8], who reported the significant effect of feeding the citric acid by-product from cassava at the level of 3-12\% on Japanese quails throughout 1-6 weeks. Citric acid waste from cassava was shown to be a viable replacement at a level of $6 \%$ throughout the entire feeding time. However, this study agrees with the result reported by Nourmohammadi et al. [19], who reported that no significant effects on feed intake in broiler chicks fed a diet supplemented with citric acid. FCR result of feeding CABR to KKU 1 chicken showed that it had no significant effect.

Survival rates in this study showed no significant effect on Thai broiler chicken when fed with CABR. Mehdikhany et al. [11] reported that organic acid could lead to a reduction in disease factors in feed, reduction in intestinal $\mathrm{pH}$ and harmful microorganisms, and elimination of pathogenic bacteria, and, finally, organic acids appear to cause improvement in the survival rates of animals. Mroz [20], reported that the addition of organic acid to the broiler diet suppressed pathogenic growth and improved digestion, absorption, mucosal immunity, and topical effects on the intestinal brush border. Thompson and Hilton [21] also found organic acid has mainly been used in order to sanitize feed to prevent issues such as salmonella infections in animals. Langhout et al. [22] also found that including organic acids in chicken rations increased performance, such as feed consumption, by strengthening the immune system of the birds, potentially lowering disease risk.

The results of villi histological assessment (Table 3) showed that $\mathrm{VH}$ was not affected by the CABR inclusion. Pelicano et al. [23] reported that the increase in the length of the villi is an attempt to increase the surface area of the intestine to maximize absorption once the digestive organs pass through the lumen. However, reduction in villus height, on the other hand, can diminish nutrient absorption by reducing the intestinal surface area available for absorption. As a result, limiting nutrient absorption lowers disease resistance and growth performance [24]. The current finding in this study is in contra with the previous study of Nasibeh et al. [25], who found that supplementation of organic acid has an effect on increasing the villi length of broilers.

CD measurements in this study showed that CABR caused a decrease compared to the control group (Table 3). Deeper crypts indicated tissue turnover in the villi due to normal 
sloughing, and also to pathogens or toxins/toxin-induced inflammation [26]. Aptekman et al. [27] reported that dietary organic acid were associated with an increase in intestinal nutrient assimilation of broiler diets. Organic acids were shown to enhance the VH in the small intestines and also to have a direct stimulatory effect on the proliferation of gastrointestinal cells. As reported by Tappenden and McBurney, short-chain fatty acids were shown to cause an increase in plasma glucagon-like peptide-2, ileal proglucagon mRNA, and expression of both glucose transporter and celluler protein, all of which are signals that can theoretically mediate the proliferation of gut epithelial cells. These histological improvements in the small intestines possibly led to an increase in the area of the intestinal surface and facilitated the absorption of nutrients to a greater extent, thus enhancing the growth-promoting impact of supplementation with organic acids [28]. Moreover, an increase in the ratio of $\mathrm{V}: \mathrm{C}$ was detected in this study when compared with the control group $(p<0.05)$. An increase in this ratio could most likely be related to digestion and absorption and cause an increase in the number of beneficial bacteria in the gut lumen [29]. Also, the increase of the ratio V:C might be associated with the increase of the number of beneficial bacteria in the gut lumen [30]. This finding is possibly due to CABR containing the remaining under-graded citric acid which has a low $\mathrm{pH}$ and might affect this ratio. This result is critical because a higher ratio of villous height to crypt depth indicates a greater capacity for nutrient digestibility and absorption in chickens. It has been established that shorter intestinal villi relative to crypt depth are associated with a lower number of absorptive cells and a higher number of secretory cells [31].

In the current study the addition of CARB although showing a decreasing tendency of E.coli colony count, no significant differences were observed in comparison to the control treatment. Islam [32] reported that citric acid offers further benefits over antibiotic growth promoters when considering performance, non-specific immunity, and bone formation. Organic acids have antimicrobial effects because they diffuse through the bacterial cell membrane, dissociate into anions and protons, and, eventually, disturb the intracellular electron balance [33]. The incorporation of citric acid, especially at the 4.5 and $6 \%$ in drinking water, caused a significant decline of Bacillus, Clostridium, Coliform, and facultative aerobic bacteria, and other bacteria in the gizzard, ceca, and feces [34]. Organic acids reduce the growth of many pathogenic or nonpathogenic bacteria in the gut lumen [35].

\section{Conclusions}

In conclusion, supplementation with CABR produced no negative effects on the growth performance of Thai broiler chickens (KKU 1) and had a significant effect on the villi histological properties of broiler chicks. The addition of CABR did not affect the VH section (duodenum and ileum), but has the effect of decreased CD and increased ratio of $\mathrm{V}: \mathrm{C}$ when compared with the control group, which indicates that CABR should be considered appropriately when used as a corn replacement in the diets. Moreover, the addition of CABR in feed has no effect in E.coli colonies of broiler fecal matter. Therefore, CABR may successfully be used in Thai broiler chicken (KKU 1) diet.

Author Contributions: Conceptualization, M.O., S.W., B.T., A.C., S.T., P.P. and N.P.; methodology, M.O., S.W. B.T., A.C., S.T. and P.P.; software, P.P., W.B. and M.O.; validation, S.W., B.T. and A.C.; formal analysis, M.O., P.P., N.P. and B.T.; investigation, M.O., S.W. and B.T.; resources, S.W. and B.T.; data curation, S.W., B.T., W.B. and A.C.; writing-original draft preparation, M.O., S.W. and A.C.; writing-review and editing, M.O., B.T. and S.W.; visualization, M.O. and P.P.; supervision, M.O., S.W., B.T., W.B. and A.C.; project administration, S.W., B.T. and A.C.; funding acquisition, S.W. and B.T. All authors have read and agreed to the published version of the manuscript.

Funding: This research was funded by the Program on Toxic Substances, Microorganisms and Feed Additives in Livestock and Aquatic Animals for Food Safety, Khon Ken University, Thailand (Grant No. KKU-RP64-10-005).

Institutional Review Board Statement: Ethical reviewed and approved by the Institutional Animal Care and Use Committee of Khon Kaen University, based on the Ethic of Animal Experimentation of 
National Research Council of Thailand (Date of Approval: 23 July 2020) (Record No. IACUC-KKU69/63).

Informed Consent Statement: Not applicable.

Data Availability Statement: Data are contained within the article.

Acknowledgments: The authors would like to express their genuine gratitude to the Network Center for Animal Breeding and Omics Research, Faculty of Agriculture, Khon Kaen University, Thailand, PS Nutrition Company Limited for giving the offices of this exploration, and Animal Supplementation and Pharmaceutical Co., Ltd. (Vet products Group) for providing their product (premix) in this study.

Conflicts of Interest: The authors declare no conflict of interest. The funders had no role in the design of the study; in the collection, analyses, or interpretation of data; in the writing of the manuscript, or in the decision to publish the results.

\section{References}

1. Dhillon, G.; Brar, S.; Dhillon, S.; Verma, M. Bioproduction and extraction optimization of citric acid from Aspergillus niger by rotating drum type solid-state bioreactor. Ind. Crops Prod. 2013, 41, 78-84. [CrossRef]

2. Kudzai, C.T.; Ajay, K.; Ambika, P. Citric acid production by Aspergillus niger using different substrates. Malays. J. Microbiol. 2018, 12, 199-204. [CrossRef]

3. Ngammuangtueng, P.; Jakrawatana, N.; Nilsalab, P. Water, Energy and Food Nexus in Rice Production in Thailand. Sustainability 2019, 11, 5852. [CrossRef]

4. Imandi, S.B.; Bandaru, V.V.R.; Somalanka, S.R.; Bandaru, S.R.; Garapati, H.R. Application of statistical experimental designs for the optimization of medium constituents for the production of citric acid from pineapple waste. Bioresour. Technol. 2008, 99, 4445-4450. [CrossRef]

5. Ayeni, A.O.; Daramola, M.O.; Taiwo, O.; Olanrewaju, O.I.; Oyekunle, D.T.; Sekoai, P.T.; Elehinafe, F.B. Production of Citric Acid from the Fermentation of Pineapple Waste by Aspergillus niger. Open Chem. Eng. J. 2019, 13, 88-96. [CrossRef]

6. Femi-Ola, T.O.; Atere, V.A. Citric acid production from brewers spent grain by Aspergillus niger and Saccharomyces cerevisiae. Int. J. Res. Biosci. 2013, 2, 30-36.

7. Li, X.; Li, G.; Li, J.; Yu, Y.; Feng, Y.; Chen, Q.; Komarneni, S.; Wang, Y. Producing petrochemicals from catalytic fast pyrolysis of corn fermentation residual by-products generated from citric acid production. Renew. Energy 2016, 89, 331-338. [CrossRef]

8. Tanpong, S.; Cherdthong, A.; Tengjaroenkul, B.; Reungsang, A.; Sutthibak, N.; Wongtangtintharn, S. A study on citric acid by-product as an energy source for Japanese quail. Trop. Anim. Health Prod. 2021, 53, 474. [CrossRef]

9. Rehman, Z.; Mirza, M.; Mukhtar, N. Poultry Research Use of Organic Acids as Potential Feed Additives in Poultry Production. J. World's Poult. Res. 2016, 6, 105-116.

10. Tanpong, S.; Cherdthong, A.; Tengjaroenkul, B.; Tengjaroenkul, U.; Wongtangtintharn, S. Evaluation of physical and chemical properties of citric acid industrial waste. Trop. Anim. Health Prod. 2019, 51, 2167-2174. [CrossRef]

11. Mehdikhany, S.; Zarei, A.; Lotfollahian, H.; Hoseini, S.A. Determination of nutritive value and the effect of citric acid production by-product on broiler performance. Indian J. Anim. Res. 2012, 46, 143-147.

12. Oryza.S, M.; Wongtangtintharn, S.; Tengjaroenkul, B.; Cherdthong, A.; Tanpong, S.; Bunchalee, P.; Pootthachaya, P.; Reungsang, A.; Polyorach, S. Physico-Chemical Characteristics and Amino Acid Content Evaluation of Citric Acid by-Product Produced by Microbial Fermentation as a Potential Use in Animal Feed. Fermentation 2021, 7, 149. [CrossRef]

13. Xu, J.; Su, X.F.; Bao, J.W.; Chen, Y.Q.; Zhang, H.J.; Tang, L.; Wang, K.; Zhang, J.H.; Chen, X.S.; Mao, Z.G. Cleaner production of citric acid by recycling its extraction wastewater treated with anaerobic digestion and electrodialysis in an integrated citric acid-methane production process. Bioresour. Technol. 2015, 189, 186-194. [CrossRef]

14. Maliwan, P.; Khempaka, S.; Molee, W. Evaluation of various feeding programmes on growth performance, carcass and meat qualities of Thai indigenous crossbred chickens. S. Afr. J. Anim. Sci. 2017, 47, 16-25. [CrossRef]

15. Singh, A.; Rashid, M. Impact of Livestock Waste on Environment and Strategies to Reduce Environmental Contamination-A Review. Vet. Sci. J. 2018, 8, 76-86. [CrossRef]

16. De Verdal, H.; Mignon-Grasteau, S.; Jeulin, C.; le Bihan-Duval, E.; Leconte, M.; Mallet, S.; Martin, C.; Narcy, A. Digestive tract measurements and histological adaptation in broiler lines divergently selected for digestive efficiency. Poult. Sci. 2010, 89, 1955-1961. [CrossRef]

17. Bird, P.; Bastin, B.; Klass, N.; Crowley, E.; Agin, J.; Goins, D.; Bakken, H.; Lingle, C.; Schumacher, A. Evaluation of the 3MTM PetrifilmTM Rapid E. coli/ Coliform Count Plate for the Enumeration of E. coli and Coliforms: Collaborative Study, First Action: 2018.13. J. AOAC Int. 2021, 103, 513-522. [CrossRef]

18. SAS University Edition: Statistic, 6th ed.; SAS Inst. Inc.: Cary, NC, USA, 2015; Volume 9.

19. Nourmohammadi, R.; Hosseini, S.M.; Farhangfar, H. Influence of Citric Acid and Microbial Phytase on Growth Performance and Carcass Characteristics of Broiler Chickens. Am. J. Anim. Vet. Sci. 2010, 5, 282-288. [CrossRef]

20. Mroz, Z. Organic Acids as potential Alternatives to antibiotic growth promoters for pigs. Adv. Pork Prod. 2005, 16, 169-182. 
21. Thompson, J.L.; Hinton, M. Antibacterial activity of formic and propionic acids in the diet of hens on salmonellas in the crop. Br. Poult. Sci. 1997, 38, 59-65. [CrossRef]

22. Langhout, P. New additives for broiler chickens. World Poult. 2000, 16, 22-27.

23. Pelicano, E.; Souza, P.; Souza, H.; Figueiredo, D.; Boiago, M.; Carvalho, S.; Bordon, V. Intestinal mucosa development in broiler chickens fed natural growth promoters. Rev. Bras. Ciência Avícola 2005, 7, 221-229. [CrossRef]

24. Xu, Z.R.; Hu, C.H.; Xia, M.S.; Zhan, X.A.; Wang, M.Q. Effects of dietary fructooligosaccharide on digestive enzyme activities, intestinal microflora and morphology of male broilers. Poult. Sci. 2003, 82, 1030-1036. [CrossRef] [PubMed]

25. Mohammadagheri, N.; Najafi, R.; Najafi, G. Effects of dietary supplementation of organic acids and phytase on performance and intestinal histomorphology of broilers. Vet. Res. Forum Int. Q. J. 2016, 7, 189-195.

26. Yason, C.V.; Summer, B.A.; Schat, K.A. Pathogenesis of rotavirus infection in various age groups of chickens and turkeys. Am. J. Vet. Res. 1987, 48, 38. [CrossRef]

27. Aptekmann, K.P.; Baraldi Artoni, S.M.; Stefanini, M.A.; Orsi, M.A. Morphometric analysis of the intestine of domestic quails (Coturnix coturnix japonica) treated with different levels of dietary calcium. Anat. Histol. Embryol. 2001, 30, 277-280. [CrossRef]

28. Adil, S.; Banday, T.; Bhat, G.A.; Mir, M.S.; Rehman, M. Effect of dietary supplementation of organic acids on performance, intestinal histomorphology, and serum biochemistry of broiler chicken. Vet. Med. Int. 2010, 2010, 479485. [CrossRef]

29. Montagne, L.; Pluske, J.R.; Hampson, D.J. A review of interactions between dietary fibre and the intestinal mucosa, and their consequences on digestive health in young non-ruminant animals. Anim. Feed Sci. Technol. 2003, 108, 95-117. [CrossRef]

30. Garriga, M.; Pascual, M.; Monfort, J.M.; Hugas, M. Selection of lactobacilli for chicken probiotic adjuncts. J. Appl. Microbiol. 1998, 84, 125-132. [CrossRef]

31. Silva, M.; Pessotti, B.; Zanini, S.; Colnago, G.; Rodrigues, M.R.; Nunes, L.; Zanini, M.; Martins, I. Intestinal mucosa structure of broiler chickens infected experimentally with Eimeriatenella and treated with essential oil of oregano. Ciência Rural 2009, 30, 1471-1477. [CrossRef]

32. Islam, K.M.S. Use of citric acid in broiler diets. Worlds. Poult. Sci. J. 2012, 68, 104-118. [CrossRef]

33. Lückstädts, C. Use of organic acids as feed additives- sutainable aquaculture production the non-antibiotic way. Int. Aquafeed 2006, 9, 21-26. [CrossRef]

34. Kermanshahi, H.; Nassiri Moghaddam, H.; Gilani, A. Alteration of gut microflora through citric acid treated drinking water in preslaughter male broilers. Afr. J. Microbiol. Res. 2013, 7, 564-567. [CrossRef]

35. Pluske, J.R.; Thompson, M.J.; Atwood, C.S.; Bird, P.H.; Williams, I.H.; Hartmann, P.E. Maintenance of villus height and crypt depth, and enhancement of disaccharide digestion and monosaccharide absorption, in piglets fed on cows' whole milk after weaning. Br. J. Nutr. 1996, 76, 409-422. [CrossRef] [PubMed] 